\title{
Effect Of Trust, Convinience, Security And Quality Of Service On Online Purchase Decision (Consumer Case Study In Tangerang Selatan Area)
}

\author{
Indra Ade Irawan \\ Economics and Business Faculty, University of Mercu Buana \\ Email: indraadeirawan3@gmail.com
}

\begin{abstract}
This study aims to determine the influence of trust, convenience, security, and quality of service to online purchasing decisions on consumers in the area of South Tangerang. The population is all consumers who buy products online in South Tangerang region. The type of data used is the primary data using the questionnaire method. The sampling technique is using non probability sampling with sample of 200 respondents. The analysis technique used is multiple regression. The results showed that: (1) Trust has a positive and significant effect on online purchasing decisions. (2) Convinience has a positive and significant impact on online purchasing decisions. (3) Security has a negative and insignificant effect on online purchasing decisions. (4) Service Quality has a positive and significant impact on online purchasing decisions.
\end{abstract}

Keywords: Trust, Convinience, Security and Quality of Service and Purchase Decision Online

\begin{abstract}
Abstrak: Penelitian ini bertujuan untuk mengetahui pengaruh kepercayaan, kenyamanan, keamanan, dan kualitas layanan terhadap keputusan pembelian online pada konsumen di daerah Tangerang Selatan. Populasinya adalah semua konsumen yang membeli produk secara online di wilayah Tangerang Selatan. Jenis data yang digunakan adalah data primer dengan menggunakan metode kuesioner. Teknik pengambilan sampel menggunakan non probability sampling dengan sampel sebanyak 200 responden. Teknik analisis yang digunakan adalah regresi berganda. Hasil penelitian menunjukkan bahwa: (1) Kepercayaan memiliki pengaruh positif dan signifikan terhadap keputusan pembelian online. (2) Convinience memiliki dampak positif dan signifikan terhadap keputusan pembelian online. (3) Keamanan memiliki efek negatif dan tidak signifikan pada keputusan pembelian online. (4) Kualitas Layanan memiliki dampak positif dan signifikan terhadap keputusan pembelian online.
\end{abstract}

Kata kunci: Kepercayaan, Convinience, Keamanan dan Kualitas Layanan dan Keputusan Pembelian Online

\section{PRELIMINARY}

Phenomenon with a population of 250 million more, Indonesia is a very potential market for all products. However, how far is consumer loyalty in Indonesia? Apparently based on an analysis conducted by Worldpanel Indonesia as reported in Vivanews.com-Bisnis that the loyalty of Indonesian consumers is low. Opportunities to switch average brands tend to be higher than percentages to be loyal to a particular brand. For example on shampoo and soap, the percentage to replace brand $56 \%$, while the category of instant noodles $59 \%$. The same is true of gadgets, consumers are now rarely dependent on a particular brand, they 
tend to switch brands when finding products that feature or the price is more appropriate, or it could be because a good promo strategy like this happens a lot among consumers in Indonesia, even around the world. With a variety of reasons and rationale, consumers are alternating products. Gonta brand replacement symptoms are known by brandswitching, a reasonable symptom of consumer behavior. $88 \%$ of consumers in Indonesia like to experiment with different brands of products for the same category of goods. Brand switching is supported by the globalization of information networks, so that the catalog or information of an item can be obtained easily from both mass media and electronic or internet advertising. Especially television ads that can be accessed almost by all levels of society. The advertisements that aired on television media form a consumer attitude statement that affects consumer buying interest. The formation of attitudes toward advertising is influenced by consumer perceptions of advertising, therefore the more attractive an ad or the use of brand ambassador right then it will increasingly attract consumers.

Basically, manufacturers can not prevent consumers from using other products, but what can be done is to make consumers more attached to their products by building brand loyalty and customer loyalty. Brand loyalty is a positive view, a positive image that is embedded in the minds of customers of a brand. Building a strong brand loyalty can not be just from advertising or logo but must be total experience to the target so that the level of customer satisfaction is greater. A high level of satisfaction will encourage consumers to make loyal repeat purchases. While building customer loyalty is usually by increasing customer life time value, customer retention and especially improve communication with customers. The point is to make the customer more active in interacting with the company for example by frequenting the company's website or now a rampant interaction through social media. Companies that already have good customer loyalty such as Lion Air, Garuda Indonesia, BCA, and some providers. The indication of a constant complaint from customers did not make them collapse. Customer loyalty can not be permanent, easily fragile especially in the era of social media. Strong public pressure and repeated complaints that spread easily through social media will hamper their progress if they do not immediately fix themselves. Consumer tastes in terms of the availability of goods and services constantly change rapidly, the change leads to the availability of products and services with quality better. This motivates producers to innovate new innovations in delivering products and services that meet consumer expectations.

Kevin (2014) The development of Internet users are encouraging the occurrence of a major pontensi the creation of online shopping. Therefore the opportunity to run an online business more open for business in Indonesia. Online shopping is a buying and selling activity or electronic commerce that allows consumers to be able to directly buy goods or services from the seller through the internet using a web browser (en.wikipedia.org). Online shopping makes us easier to shop without spending time and effort. Because of this convenience makes online shopping more attractive

Andy Putra Mahkota (2014) The phenomenon of the increasing use of the Internet, so researchers want to know what individual perceptions that affect online purchasing decisions. Some academics such as Horppu, Kuivalainen, Tarkiainen, and Ellonen, (2008); Bigne Alcaniz, Ruiz-Mafe, Aldas-Manzano, and Sanz-Blas, (2008); Chang and Chen, (2008) examine the unifying research on consumer behavior theory for the advancement of Internet usage in purchasing decisions on goods and services. This research develops 
and analyzes previous research on which factors. affecting the online purchasing decision process.

Pudji Utomo (2014) Factors that determine the successful implementation of business (especially retail sales) online is the trust of consumer confidence on the internet. Some online consumers are afraid to carry out online transactions due to various considerations, namely: (1) High computer crime, namely the rampant burglary credit card; (2) Protection of consumers who make purchases online; (3) Online fraud

Raman Arasu and Viswanathan A. (2011), through studies conducted on online consumers in Malaysia, found that security factors have a positive and significant relationship in influencing purchasing decisions through social networking websites.

Raje Archana and Vandana T.K (2012) in his research on the effect of e-service quality on consumer purchasing behavior in online shopping, said that currently 2 prices and promotion are no longer able to determine purchasing decisions for consumers. According to him, now consumers also make an assessment on the quality of service when shopping online through social networking websites.

The research objectives as follows: (1) To know and analyze the influence of Trust on Online Purchase Decision on Consumer in South Tangerang Region; (2) To know and analyze the influence of Convinience of Online Purchasing Decision on Consumers in South Tangerang Region; (3) To know and analyze the effect of Security on Online Purchase Decision on Consumers in South Tangerang Region; (4) To know and analyze the effect of Quality of Service on Online Purchase Decision on Consumer in South Tangerang Region

Research Benefits: (1) This final work systematically and methodologically based on these research norms, in whole or in part, is generally intended to have a scientific contribution. Thus expected to be used as a reference or knowledge for researchers, practitioners and contribute to policy; (2) The results of this study conclude that trust, convenience, security, and service quality have a very important role in measuring consumer purchasing decisions online in Tangerang Selatan area where what is expected should be applied or reflected in the development of cybernet world.

\section{LITERATURE REVIEW}

Trust. The belief dimension in relation to the online shop is closely related to consumer confidence in intermediaries and online vendors (Chen and Dhillon, 2003). According to Kimery and McCard (2002), trust in online stores is a willingness to accept weaknesses in online transactions based on positive expectations about the future behavior of online stores. Gefen and Straub (2004) concluded that the higher the degree of consumer confidence, the higher the level of purchase of consumer intentions. Simply believe it needs to exist when placing an order online and when the customer sends financial information and other personal data in conducting financial transactions (Egger, 2006). Trust is a mental or verbal statement that reflects a person's particular knowledge and judgment about some idea or thing (Sciffman and Kanuk, 2000). Consumer confidence concerns the belief that a product has various attributes, and benefits from these various attributes. Consumer confidence in a product, attribute, and product benefit describes consumer perception. So the level of consumer confidence is not the same, there are higher and some are lower. Consumer Confidence: online transactions that have certainty and information that is not symmetrical. Consequently there is a need for mutual trust 
between buyers and sellers (Gefen, 2002), and many papers show that consumer confidence in e-commerce is one of the key factors. In this study, Koufaris and HamptonSosa (2004) defined initial beliefs, and further assumed that consumers with a good network of off-line stores can incrconvinience confidence in online stores.

Convenience. The next consideration for online shoppers is the convinience of use factor. This convenience factor is related to how the transaction operates online. Usually prospective buyers will experience difficulties at the first time transact online, and tend to discourage because of security factors and do not know how to transact online. On the other hand, there are also prospective buyers who take the initiative to try because it has got information about how to transact online.

Security. Raman Arasu and Viswanathan A. (2011), in Sukma (2011) through a study conducted on online consumers in Malaysia, found that security factors have a positive and significant relationship in influencing purchasing decisions online. Where consumers will not make a purchase without any security guarantees. Because without adequate security guarantees it will certainly cause concern to consumers, which ultimately prevents them from making a purchase. And conversely when the webstore able to incrconvinience security and provide assurance to the consumer then the consumer confidence in shopping will incrconvinience.

Quality of Service. Lovelock in Tjiptono (2011: 58), argued that the quality of service is the level of good condition or poor dish presented by the seller in order to satisfy the consumer by giving or convey the desire or demand of consumers beyond what is expected consumers. Parasuraman, Zeithaml and Berry in Lupiyoadi (2001: 148) mentions there are five main factors used in assessing service quality namely reliability, tangible, responsibility, assurance and empathy ). According Rahma, et al (2012) services provided by the services are different from the quality provided online. Although producers can not meet face-to-face, manufacturers can provide it through the appearance of products that consumers see, the accuracy of existing products in real-world images and products, to the safety that manufacturers provide to consumers about personal data for the purpose of delivering products.

Buying decision. In general the decision is the election of two or more alternative options (Schiffman \& Kanuk, 2000). In other words to make a decision there must be an alternative option. Conversely, if consumers do not have an alternative to choose then it can not be categorized as a decision. Purchasing decisions are individual activities that are directly involved in making decisions to make purchases of products offered by the seller. Understanding purchasing decisions, according to Kotler and Armstrong (2001) is the stage in the decision-making process of buyers where consumers actually buy 
Research Framework. The framework of this research is presented in the picture below:

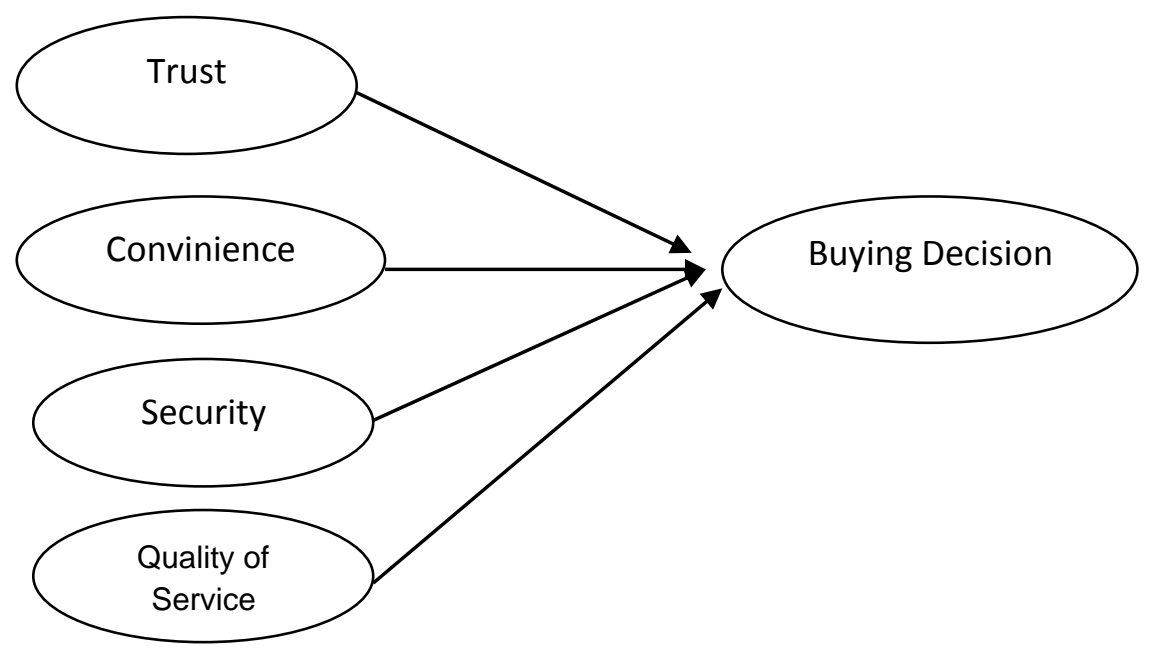

Figure 1. Thought Framework

Research Hypothesis. The hypothesis is a temporary answer to the problem under study and the truth needs to be tested empirically. This study uses a causal hypothesis study that states the influence of a variable on other variables.

1. H1 = Trust has a significant effect on the Purchase Decision Online on consumers in the area of South Tangerang

2. $\mathrm{H} 2$ = Convinience of significant effect on the Purchase Decision Online to consumers in the area of South Tangerang

3. $\mathrm{H} 3$ = Security has significant effect on Online Purchase Decision to consumer in Tangerang Selatan area

4. H4 = Service Quality Significant effect on Online Purchase Decision to consumers in Tangerang Selatan region

\section{RESEARCH METHODS}

Research Methods. In writing this thesis, the author uses a method of causal research that aims to meguji about the influence, between a variable (Indenpenden / Xn) with other variables (Dependent Variables / Yn). In this case the quality of Education (Xn) consists of indicators: $\mathrm{X} 1=$ Trust, $\mathrm{X} 2=$ Convenience, $\mathrm{X} 3=$ Security and X4 $=$ Quality of Service. While $\mathrm{Y}=$ Purchasing Decision Online Consumer Region South Tangerang as variable Dependen. This research requires hypothesis testing with statistical test.

\section{Definition and Operational Variables}

Operational definition of a variable is a definition given to a variable by giving meaning, or providing an operational needed to measure the variable. The Variable Operational Definition used by the author in conducting the preparation of this research are:

a. Trust. A general belief or a belief that others can be trusted; or a party's willingness to be sensitive to the actions of others (Kim et al, in Sukma, Abdurrahman Adi., 2012). 
b. Convenience. Kevin (2014) Online shopping makes us easier to shop without spending time and effort. Because of this convenience makes online shopping more attractive.

c. Security. Security or security as an online store capability in controlling and maintaining security of data transactions (Raman Arasu and Viswanathan A., 2011)

d. Quality of Service. The level of good condition of poor dish presented by the seller in order to satisfy the consumer by giving or convey the desire or demand of consumers beyond what is expected by consumers. (Raje Archana and Vandana T.K, 2012).

Determination of Research Sample. Population refers to the entire group of people, events, or interests to be investigated (Now, 2006). Population used in this research is consumer in South Tangerang region. The sampling technique in this research is incidental sampling technique, by distributing questionnaires to the respondents encountered by the writer in Tangerang Selatan region according to his profession. The reason for selecting this sampling technique is to simplify the sampling process. (Fikriningrum, 2012: 34). Roscoe (1975) in Sekaran (1992) stated that: 1. The number of samples sufficient for the study is in the range of 30 to 500. In studies using multivariate analysis (such as multiple regression analysis), the sample size must be at least 10 times greater than the number of independent variables. Meanwhile, Tabachnick and Fidell (1997) in (Hair, 1998), the required sample size is between 5 - 10 times the number of parameters. With the number of research parameters, in this case is the number of constructors indicator of 20 , then the number of respondents ideally is between 100-200 respondents.

Data Analysis Method. The method of analysis of research data as follows:

1. Test Validity and Realibility: (a) Validity test. Validation test is used to measure the validity or validity of a questionnaire. The questionnaire is said to be valid if the question on the questionnaire is able to reveal something that will be measured by the questionnaire; (b) Test Reliability. Reliability test is a measuring tool for a stability and consistency of respondents in answering matters relating to construct - construct question which is an indicator of a variable and arranged in a form of questionnaire.

2. Descriptive Statistics Analysis. Descriptive statistics are statistics used to analyze data by way of describing or describing data that has been collected as is without intending to make conclusions that apply to the public or generalization.

3. Classic Assumption Test: (a) Normality test. Normality test is used to determine whether the data is normally distributed or not. The normalized level of data is very important, because with normally distributed data, then the data is considered to be representative of the population. (b) Test Multicolonierity. Multicolonierity test aims to test whether the regression model found the correlation between independent variables (Independent). A good regression model should not be correlated between independent variables. (c) Heteroscedasticity Test. Heteroscedasticity test aims to test whether the regression model of variance inequality occurs from one observation to another observation remains, so called Homoskedastisitas and if different is called Heteroscedasticity.

4. Hypothesis Testing: (a) Coefficient of Determination Test. Test Coefficient determines to see how big variable X1, X2 and X3 have relation to variable $\mathrm{Y}$, hence used coefficient of determination $(\mathrm{Kd})$ which is correlation square; (b) Whole or Simultaneous Testing ( $\mathrm{F}$ Test). $\mathrm{F}$ test is done to know the relation of independent variable simultaneously to the dependent variable then used significant level 0,05.; (c) Individual or Persial Testing (t- 
test). To know the assumption or guess is true or not, then conducted a test called t test. T test is a procedure that allows the decision whether the decision is accepted or rejected on the assumption or hypothesis proposed. (Source Nila Hapsari, 2013); (d) Multiple Linear Regression Analysis. Multiple linear regression analysis is used to determine the effect of two or more independent variables with one dependent variable, whether each independent variable is positively or negatively related to the dependent variable.

\section{RESEARCH RESULT AND DISCUSSION}

Effect of Trust on Online Purchase Decision. Based on t test results obtained t count value of 1.780 is greater than t table 0.675 with a significance level of 0.002 . Therefore thitung > ttabel with significance level $<0,05$ hence can be seen $\mathrm{H} 1$ accepted and trust variable have an effect on signifikan to Purchasing Decision Online to consumer in South Tangerang region. The results of this study are in line with the research of Abdurrahman Adi Sukma (2012), Lia Suprihartini (2012) which states that trust variables significantly affect purchasing decisions.

The Effect of Convenience to Online Purchasing Decisions. Based on t test results obtained $t$ count value of 1.981 greater than $t$ table 0.675 with a significance level of 0.003 . Therefore thitung $>$ ttabel with level of significance $<0,05$ hence can be seen $\mathrm{H} 2$ accepted and variable of Convinience have significant effect to Purchasing Decision Online to consumer in South Tangerang region. The results of this study are in line with Kevin's (2014) study which states that the convenience variable significantly affects purchasing decisions

The Effects of Security on Online Purchase Decisions. Based on t test results obtained $t$ count value of 0.320 is smaller than t table 0.675 with significance level 0.72 . Therefore thitung <ttabel with significance level> 0,05 hence can be seen rejected H3 and Security variables have no significant effect to Purchase Decision Online to consumer in South Tangerang region. The results of this study are not in line with the research of Abdurrahman Adi Sukma (2012), Lia Suprihartini (2012) which states that Security variables significantly affect purchasing decisions

The Impact of Service Quality on Online Purchase Decision. Based on t test results obtained t count value of 2.260 is greater than at $t$ table 0.675 with a significance level of 0.001 . Therefore thitung $>$ ttabel with level of significance $<0,05 \mathrm{~h} 4$ can be seen is accepted and variable of Service Quality have significant effect to Purchasing Decision Online to consumer in Tangerang Selatan area. The results of this study are in line with the research of Abdurrahman Adi Sukma (2012), Lia Suprihartini (2012) which states that service quality variables significantly influence purchasing decisions

\section{CONCLUSIONS AND RECOMMENDATIONS}

Conclusion. Based on the research that has been done then can be obtained conclusion as follows: (1) Trust positively and positively affects consumer purchasing decisions online in Tangerang Selatan region; (2) Convinience of positive and significant impact for online purchasing decisions on consumers in the South Tangerang region; (3) Security has a 
negative and insignificant effect to online purchasing decisions on consumers in the South Tangerang region; (4) Quality of Service has a positive effect and significant impact on consumer purchasing decisions online in Tangerang Selatan area.

Suggestion. Based on the conclusions of this research, the following suggestions are proposed: (1) Online sales will be more trusted by consumers when given a variety of service facilities to facilitate consumers in conducting activities relations / transactions with the company; (2) Information through the online store that is presented properly and correctly will give a good image of the store, therefore the seriousness in managing stores online is very emphasized; (3) Transaction security is a very important factor should be improved because it will affect consumer confidence

\section{REFERENCE}

Adi, Rifki Nugroho. (2008). “Analisisi Faktor-Faktor yang Mempengaruhi Keputusan Pembelian dengan Sistem Pre-Order secara Online (Studi Kasus pada Online Shop Choper Jersey". Skripsi UNDIP.

Andi, dkk. ( 2014). "Pengaruh Kepercayaan Dan Kenyamanan Terhadap Keputusan Pembelian Online (Studi Pada Pelanggan Website Ride Inc)". Jurnal Administrasi Bisnis (JAB)|, 8 (2), Maret

Elissa, Ingge dan Mujiyana. (2013). "Analisis Faktor-Faktor yang Mempengaruhi Keputusan Pembelian Via Internet pada Toko Online”. Jurnal Ekonomi Manajemen Universitas Diponegoro.

Ferdinand, Agusty T. (2006). Metode Penelitian Manajemen. Badan Penerbit Undip. Semarang.

Ghozali, Imam. (2006). Aplikasi Analisis Multivariate dengan Program SPSS. Badan Penerbit UNDIP, Semarang.

Ghozali, Imam. (2012). Aplikasi Analisis Multivariate dengan Program SPSS 20. Badan Penerbit UNDIP, Semarang.

Isnain Putra Baskara (2013). Analisis Pengaruh Kepercayaan, Keamanan, Kualitas Pelayanan Dan Persepsi Akan Resiko Terhadap Keputusan Pembelian Melalui Situs Jejaring Sosial (Social Networking Websites) (Studi Pada Mahasiswa Di Kota Semarang)

Kevin (2014). “Analisis Pengaruh Kepercayaan, Kemudahan, Dan Keragaman Produk Pakaian Via Online Terhadap Keputusan Pembelian Secara Online

(Studi kasus pada mahasiswa belanja online pada FEB Universitas Muhammadiyah Surakarta)". Skripsi Universitas Muhammadiyah Surakarta

Lupiyoadi, Rambat. (2001). Manajemen Pemasaran Jasa; Teori dan Praktik (Edisi Pertama). Penerbit Salemba Empat. Jakarta.

Nancy, Lee dan Philip Kotler. (2005). Corporat Social Responsibility. Amerika: John Wiley and Sons, Inc.

Mardhotillah, Izzati Choirini dan Saino. (2013). "Pengaruh Kualitas Layanan terhadap Keputusan Pembelian Konsumen di Surabaya". Jurnal Universitas Negeri Surabaya.

Pavlou, P. A., dan Gefen, D., (2002). "Building Effective Online Marketplaces with Institution-based Trust", Proceedings of Twenty-Third International Conference on Information Systems, pp. 667-675. 
Pudji utomo, dkk (2014). Kepercayaan Terhadap Internet Serta Pengaruhnya Pada Pencarian Informasi Dan Keingingan Membeli Secara Online

Raje, Archana., dan Vandana, Tandon Khanna. (2012). "Impact of E-Service Quality on Consumer Purchase Behaviour in an On-line Shopping”. IJCSMS International Journal of Computer Science and Management Studies, 12 (02), 1-5.

Rahma dkk. (2012). "Hubungan Antara Kualitas Layanan dan Harga dengan Kepuasan Konsumen Onlne Shopping pada Mahasisa Unversitas Surabaya”. Jurnal Universitas Surabaya.

Raman, Arasu., dan Viswanathan, A. (2011). Web Services and e-Shopping Decisions: A Study on Malaysian e-Consumer. IJCA Special Issue on:Wireless Information Networks \& Business Information System, hal.54-60.

Schiffinan LG dan LL Kanuk.(1994). Consumer Behavior. London : Prentice Hall International.

Schiffman, L dan L. Kanuk. (2004). Consumer Behaviour. Prentice Hall. New Jersey

Sugiyono. (1999). Statistika untuk Penelitian. Bandung: Alfabeta.

Sugiyono. (2008). Metode Penelitian Bisnis. Bandung. Alfabeta.

Sukma, Abdurrahman Adi., (2012) "Analisis Faktor-Faktor Yang Mempengaruhi Keputusan Pembelian Social Networking Websites", Jurnal Ekonomi Manajemen, Fakultas Ekonomi Universitas Gunadarma.

Sularto, Lana. (2004). "Pengaruh Privasi ,Kepercayaan Dan Pengalaman Terhadap Niat Beli Konsumen Melalui Internet”. Jurnal Ekonomi \& Bisnis, 3 (9), 138-155.

Supranto, J. (2001). Pengukuran Tingkat Kepuasan Pelanggan. Jakarta: PT Rineka Cipta.

Suresh, A.M., dan Shashikala R. (2011). Identifying Factors of Consumer Perceived Risk towards Online Shopping in India. IPEDR. 12, 336-341.

Tjiptono, Fandy. (2011). Pemasaran Jasa. Penerbit Bayumedia Publishing. Malang.

Thomson, 2013. Analisis Pegaruh Kualitas Pelayanan Konsumen Pada Warung Ucok Durian Iskandar Muda Medan Terhadap Keputusan Pembelian. FE USU. 